
ISSN : 2615-1995, E-ISSN : 2615-0654

J. Madani., Vol. 3, No. 2, September 2020 (174 - 185)

(C)2018 Lembaga Kajian Demokrasi

\title{
Anteseden dan Konsekuensi Dari Perceived Trustworthiness Pada Produk Jersey Tim Sepakbola di Online Shop Kaskus
}

\author{
Pandu Adiguna \\ Fakultas Ekonomi, Universitas Pamulang \\ panduadiguna@gmail.com \\ Nugroho Widhi Pratomo \\ Fakultas Ekonomi, Universitas Pamulang \\ widhinugroho900@gmail.com
}

\begin{abstract}
Abstrak
Tujuan dari penelitian ini adalah menganalisis pengaruh sikap perilaku, pengaruh persepsi kognitif, pengaruh keamanan yang dirasakan, pengaruh privasi yang dirasakan dan pengaruh persepsi kepercayaan. Pengambilan sampel dengan teknik purposive sampling dari seorang pria yang menggunakan kaus asli atau tidak asli sebagai responden memberikan data yang dianalisis untuk penelitian ini. Menggunakan sub-set sampel yang terdiri dari seorang pria yang menggunakan jersey asli atau tidak asli digunakan untuk menguji enam hubungan hipotesis dalam model. Analisis data dalam penelitian ini menggunakan pemodelan persamaan struktural (SEM) untuk menguji pengaruh variabel independen terhadap variabel dependen. Hasil penelitian ini menyimpulkan bahwa pengaruh kepercayaan yang dirasakan secara positif dan signifikan terhadap perilaku pembelian pelanggan produk toko online di media sosial. kaskus.
\end{abstract}

Kata Kunci : Sikap Perilaku, Persepsi Kognitif, keamanan, Privasi, Kepercayaan

\begin{abstract}
The objectives of this research was analyzed the effect of behavioral attitude, the effect of cognitive perception, the effect of perceived security, the effect of perceived privacy and the effect of perceived trustworthiness. A sampling with purposive sampling techniques of a man who use original or non original jersey as the respondents provided the data that were analyzed for this study. Using a sub-set of the sample consisting of a man who use original or non original jersey was used to test six hypothesized relationships in the model. Data analysis in this research was used structural equation modelling (SEM) to test the independent variables influence the dependent variable. The result of this research conclude that the effect of positively and significantly perceived trustworthiness towards purchase behavior customer of online shop product in social media kaskus.
\end{abstract}

Keywords : Behavioral Attitude, Cognitive Perception, Security, Privacy, Trustworthiness

\section{PENDAHULUAN}

Dewasa ini teknologi informasi berkembang dengan sangat pesat. Sistem teknologi informasi sangat berguna bagi kehidupan manusia. Dengan adanya sistem teknologi informasi akan menimbulkan penerimaan atau penolakan masuknya sistem teknologi informasi (Davis, 1989). Sistem teknologi dapat diterima baik oleh penggunanya, maka perilaku menolak untuk menggunakan teknologi perlu diubah atau sistem perlu 
dipersiapkan dahulu agar lebih mudah digunakan oleh pengguna. Adanya perkembangan teknologi informasi melalui penggunaan internet dapat meningkatkan kinerja dan pendapatan penjualan perusahaan (Ifinedo, 2011). Definisi e-commerce menurut Laudon \& Laudon (1998), e-commerce adalah suatu proses membeli dan menjual produk-produk secara elektronik oleh konsumen dan dari perusahaan ke perusahaan dengan komputer sebagai perantara transaksi bisnis. E-commerce merupakan pertukaran bisnis yang rutin dengan menggunakan transmisi Electronic Data Interchange (EDI), email, electromic bulletin boards, mesin faksimili, dan Electronic Funds Transfer yeng berkenaan dengan transaksi-transaksi belanja internet shopping, stock online dan surat obligasi, download dan penjualan software, dokumen, grafik, musik dan lain-lainnya, serta transaksi Business to Business (B2B) (Wahana Komputer Semarang, 2002). Dalam era globalisasi ini terlihat bahwa perkembangan teknologi informasi semakin canggih. Dalam penelitian ini akan membahas tentang para pengguna online shopping. Para pengguna online shopping yang menerima perkembangan teknologi informasi ditunjukkan dengan adanya keinginan untuk menggunakan teknologi informasi oleh para pengguna. Kepuasan dari informasi yang diperoleh dari para pengguna dan pengguna suatu sistem oleh para pengguna merupakan indikator penting dalam penerimaan teknologi informasi oleh para pengguna (Pijpers dan van Montfort, 2005).

Para pengguna online shopping dapat menggunakan teknologi informasi sebagai cara berbelanja yang mudah dengan melalui internet. Perdagangan melalui internet dengan menggunakan jaringan untuk menyampaikan data antar devices dengan perangkat lainnya tanpa menggunakan kabel (Coursaris et.al, 2003). Perkembangan teknologi informasi memiliki nilai perceived ease of use bagi para pengguna internet untuk melakukan promosi suatu produk atau layanan jasa secara interaktif melalui saluran komunikasi langsung melalui internet, menciptakan saluran distribusi baru yang bisa menjangkau lebih banyak pelanggan di hampir semua belahan dunia, layanan pelanggan yang lebih responsif dan memuaskan, karena pelanggan bisa mendapatkan informasi lebih rinci dan merespon secara lebih cepat dengan menggunakan internet, menghemat biaya dan waktu dalam menangani pesanan, karena sistem pemesanan melalui internet memungkinkan proses menjadi lebih cepat dan akurat. Manfaat dari nilai perceived ease of use ketika menggunakan sistem teknologi informasi adalah untuk meningkatkan pengalaman dalam menggunakan teknologi (Kim dan Forsythe, 2010).

Nilai perceived ease of use ditunjukkan ketika adanya suatu persepsi individu berpengaruh dengan kemudahan penggunaan suatu sistem dipengaruhi oleh kemampuan diri sendiri dalam menggunakan komputer dan penggunaan sistem karena individu tersebut memiliki pengalaman sebelumnya dalam menggunakan suatu sistem teknologi informasi (Dasgupta, 2002). Adanya perbedaan penilaian dari individu mengenai penyebaran teknologi informasi yaitu kecemasan ketika menggunakan teknologi informasi dan kemampuan diri sendiri dalam menggunakan teknologi informasi (Thatcher et.al., 2002). Para penggunaseharusnya dapatmengurangiketakutan atau kecemasan ketika menggunakan teknologi informasi dengan bersikap keingintahuan untuk menerima suatu teknologi dengan mempelajari dan memperhatikan petunjuk yang ada dalam situs internet. Ketakutan dalam menggunakan komputer seperti kehilangan data atau ketakutan dalam melakukan kesalahan dalam menggunakan komputer sering kali terjadi pada para pengguna teknologi informasi. Telah dinyatakan bahwa ketakutan akan berpengaruh negatif terhadap penerimaan teknologi informasi (McFarland dan Hamilton, 2006).

Para pengguna lebih memilih berbelanja melalui internet karena terlihat lebih fleksibel, lebih mudah dilakukan, dan pembayaran dilakukan melalui cara yang lebih mudah. Para pelanggan yang merasa loyal terhadap suatu merek tertentu karena para pelanggan mengetahui keunggulan dari suatu merek tertentu dengan cara melakukan transaksi pembelian melalui internet. Adapun beberapa faktor yang menentukan loyalitas merek suatu produk atau layanan jasa yang dimiliki 
oleh para pelanggan seperti rencana penggunaan internet untuk berbelanja, kegunaan yang dirasakan ketika berbelanja melalui internet, kemudahan yang dirasakan ketika berbelanja melalui internet, dan kemudahan dalam memperoleh perusahaan penyedia layanan jasa melalui internet (Purkayastha, 2009). Para pelanggan dapat melakukan transaksi secara mobile seperti penggunaan Blackberry, IPad, dan Samsung Galaxy Tab. Banyak perusahaan penyedia layanan jasa menggunakan internet sebagai cara untuk meningkatkan loyalitas merek terhadap suatu produk atau layanan jasa melalui pembentukan strategi pemasaran seperti iklan dan promosi harga. Loyalitas merek dapat meningkatkan arus kas dan profitabilitas karena para pelanggan yang loyal terhadap suatu produk atau layanan jasa akan membayar dengan harga yang lebih tinggi pada merek yang disukainya (Davis, 2002).

Dalam menggunakan mobile commerce para pengguna harus mempertimbangkan keamanan ketika melakukan transaksi. Security penting karena keamanan digunakan untuk melindungi informasi yang bersifat rahasia yang digunakan oleh para pengguna mobile phone (Lee dan Park, 2006). Lee dan Park juga menjelaskan bahwa informasi yang bersifat rahasia harus dilindungi oleh kata sandi (password) agar data dari para pengguna $m$-commerce dapat terlindungi dan tetap bersifat rahasia. Dalam penelitian terdahulu hanya meneliti variabel anxiety, mobile skillfulness, enjoyment, usefulness, dan intention to use mobile shopping. Perbedaan penelitian dengan sebelumnya adalah dengan meneliti variabelvariabel baru yaitu behavioral attitude, cognitive perception, perceived security, perceived privacy, fulfilment, perceived trustworthiness, dan purchase behavior.

Lee dan Park juga menjelaskan bahwa informasi yang bersifat rahasia harus dilindungi oleh kata sandi (password) agar data dari para pengguna $m$-commerce dapat terlindungi dan tetap bersifat rahasia. Dalam penelitian terdahulu hanya meneliti variabel anxiety, mobile skillfulness, enjoyment, usefulness, dan intention to use mobile shopping. Perbedaan penelitian dengan sebelumnya meneliti variabel-variabel baru yaitu behavioral attitude, cognitive perception, perceived security, perceived privacy, fulfillment, perceived trustworthiness, dan purchase behavior. Tujuan dari penelitian ini menganalisis pengaruh sikap perilaku, pengaruh persepsi kognitif, pengaruh keamanan yang dirasakan, pengaruh privasi yang dirasakan dan pengaruh persepsi kepercayaan.

\section{METODE}

Penelitian ini mengacu pada penelitian yang dilakukan oleh Mahmud A. Shareef, Norm Archer, Wilfred Fong, Mir Obaidur Rahman, dan Inder Jit Mann (2013) yang berjudul "Online Buying Behavior and Perceived Trustworthiness" dan penelitian yang dilakukan oleh Oliver B. Buttner dan Anja S. Goritz (2008) dengan judul "Perceived Trustworthiness of Online Shops" yang bertujuan untuk menganalisa pengaruh behavioral attitude, cognitive perception, perceived security, perceived privacy, dan fulfillment melalui social media terhadap perceived trustworthiness dan purchase behavior. Penelitian ini bersifat uji hipotesis (Hypotheses Testing) yang menjelaskan bahwa penelitian ini menjelaskan karakteristikkarakteristik tertentu.

\section{Variabel dan Pengukuran}

Variabel yang diteliti adalah behavioral attitude, cognitive perception, perceived security, perceived privacy, fulfilment, perceived trustworthiness, dan purchase behavior. Adapun pengukuran dari masing-masing variabel yang menggunakan beberapa indikator pernyataan sebagai berikut:

\section{Behavioral Attitude}

Behavioral attitude diukur dengan lima butir pernyataan yang dikembangkan oleh Shareef MA, Kumar U, dan Kumar V (2008), sebagai berikut:

1. Saya percaya pada umumnya manusia memiliki sifat yang jujur.

2. Saya percaya pada umumnya manusia memiliki sifat penolong.

3. Saya percaya pada umumnya manusia dapat dipercaya.

4. Saya percaya bahwa pemerintah memperha- 
tikan minat penduduknya.

5. Saya percaya bahwa masyarakat memperhatikan minat masyarakat lainnya.

\section{Cognitive Perception}

Cognitive perception diukur dengan tiga butir pernyataan yang dikembangkan oleh Shareef MA, Kumar U, dan Kumar V (2008), sebagai berikut:

1. Saya merasakan bahwa hukum pemerintah dapat melindungi kecurangan-kecurangan dalam pembelian melalui internet.

2. Saya merasakan bahwa kebijakan hukum dalam suatu perusahaan dapat melindungi dari kecurangan yang terjadi.

3. Saya merasakan bahwa lembaga persatuan konsumen dapat melindungi kecurangan yang terjadi.

\section{Perceived Security}

Perceived security diukur dengan empat butir pernyataan yang dikembangkan oleh Shareef MA, Kumar U, Kumar V, dan Dwivedi YK (2011), sebagai berikut:

1. Situs web merupakan suatu media yang dapat melindungi segala hal yang berhubungan dengan aktivitas keuangan.

2. Situs web memiliki sistem pengamanan yang memadai.

3. Situs web dapat melindungi segala informasi yang berhubungan dengan kartu kredit saya.

4. Kebijakan pengamanan yang terdapat dalam situs web sudah ditetapkan dengan jelas.

\section{Perceived Privacy}

Perceived privacy diukur dengan tiga butir pernyataan yang dikembangkan oleh Shareef MA, Kumar U, Kumar V, dan Dwivedi YK (2011), sebagai berikut:

1. Saya ragu-ragu untuk memberikan informasi kepada situs web.

2. Situs web dapat melindungi informasi-informasi yang telah diketahui oleh pihak lain.

3. Situs web tidak akan menyebarkan informasi pribadi saya kepada situs lainnya.

\section{Fulfillment}

Fulfilment diukur dengan enam butir per- nyataan yang dikembangkan oleh Shareef MA, Kumar U, Kumar V (2008) dan Shareef MA, Kumar U, Kumar V, Dwivedi YK (2011), sebagai berikut:

1. Saat ini situs web dapat memberikan infor masi yang tepat.

2. Segala jenis produk dan jasa yang tersedia dalam situs web menawarkan harga yang masuk akal.

3. Situs web dapat mengirimkan pesanan dengan tepat waktu.

4. Situs ini menyediakan barang-barang yang siap untuk dikirim dalam jangka waktu yang telah ditentukan.

5. Situs ini mengirimkan barang yang sesuai dengan pesanan.

6. Situs ini memiliki persediaan barang yang diinginkan.

\section{Perceived Trustworthiness}

Perceived trustworthiness diukur dengan lima butir pernyataan yang dikembangkan oleh Gefen D (2002), Shareef MA, Kumar U, Kumar V (2008) dan Shareef MA, Kumar U, Kumar V, Dwivedi YK (2011), sebagai berikut:

1. Apa yang saya lakukan melalui situs ini sudah terjamin.

2. Situs ini memiliki tanggapan yang cepat ketika saya melakukan komplain.

3. Situs ini bertanggung jawab penuh dari segala sesuatu yang tidak aman selama melakukan interaksi/melakukan transaksi di situs ini.

4. Kebijakan hukum dan teknologi dari situs ini cukup melindungi saya dari masalah yang terjadi di internet.

5. Situs ini sudah sesuai dengan standar yang ditawarkan.

\section{Purchase Behavior}

Purchase behavior diukur dengan empat butir pernyataan yang dikembangkan oleh Shareef MA, Kumar U, dan Kumar V (2008), sebagai berikut:

1. Saya membeli dari situs web.

2. Saya memiliki niat untuk kembali membeli melalui situs ini.

3. Saya akan merekomendasikan kepada teman-teman saya untuk membeli produk di 
situs ini.

4. Saya merasa puas dengan kualitas produk yang saya beli di situs ini.

Skala pengukuran yang digunakan dalam penelitian ini adalah interval metode pengukuran skala Likert. Skala Likert merupakan metode yang mengukur sikap dengan menyatakan setuju atau ketidaksetujuannya terhadap subyek, obyek atau kejadian tertentu. Skala yang digunakan adalah Skala Likert - lima point dengan susunan interval skala 1 hingga skala 5 sebagai berikut:

1) Sangat Tidak Setuju,

2) Tidak setuju,

3) Netral,

4) Setuju,

5) Sangat Setuju.

Pembentukan penelitian telah dioperasionalisasikan melalui pembahasan pustaka dengan beberapa perubahan yang dirancang untuk mengungkapkan skala penelitian (terdapat dalam Appendiks).

\section{Sampel dan Pengumpulan Data}

Dalam penelitian ini menyebarkan kuesioner kepada 160 orang mahasiswa Universitas Trisakti yang pernah berbelanja dan melakukan transaksi secara online di online shop yang tersedia dalam social media Kaskus sebagai responden. Teknik pengambilan sampel yang digunakan adalah purposive sampling. Purposive sampling adalah suatu teknik pengumpulan data berdasarkan kriteria-kriteria penelitian tertentu. Kriteria penelitian ini adalah responden berjenis kelamin pria yang menyukai sepakbola dan futsal di Universitas Trisakti, Grogol dan memiliki jersey (kostum klub sepakbola) original dan non original.

Dari total sample sebanyak 160 responden, 10 kuesioner dinyatakan tidak valid untuk dijadikan data penelitian dan 150 kuesioner valid. Adapun profil responden sebagai berikut:

\begin{tabular}{l}
\hline \multicolumn{4}{|c|}{ Tabel 1. Karakteristik Demografis Responden } \\
\begin{tabular}{|c|l|c|c|}
\hline No & \multicolumn{1}{|c|}{ Karakteristik Responden } & Frekuensi & Persentase $(\%)$ \\
\hline \multirow{2}{*}{1} & Usia: \\
\cline { 2 - 5 } & a. 17 Tahun - 20 Tahun & 63 & 42.00 \\
\cline { 2 - 5 } & b. 21 Tahun - 29 Tahun & 78 & 52.00 \\
\cline { 2 - 5 } & c. > 30 Tahun & 9 & 6.00 \\
\hline
\end{tabular}
\end{tabular}

\begin{tabular}{|c|c|c|c|}
\hline No & Karakteristik Responden & Frekuensi & Persentase $(\%)$ \\
\hline \multirow[t]{4}{*}{2} & \multicolumn{3}{|l|}{ Pendidikan Terakhir: } \\
\hline & a. SMA & 87 & 58.00 \\
\hline & b. Diploma & 22 & 8.00 \\
\hline & c. Sarjana Strata 1 & 41 & 34.00 \\
\hline \multirow[t]{4}{*}{3} & \multicolumn{3}{|l|}{ Penghasilan per bulan: } \\
\hline & a. < Rp1.000.000,- & 91 & 60.70 \\
\hline & b. Rp1.000.000,- s/d Rp5.000.000,- & 53 & 22.00 \\
\hline & c. > Rp5.000.000,- & 6 & 4.00 \\
\hline \multirow[t]{4}{*}{4} & \multicolumn{3}{|l|}{ Jersey Klub yang dibeli: } \\
\hline & a. Jersey Klub Liga Inggris & 78 & 52.00 \\
\hline & b. Jersey Klub Liga Italia & 33 & 22.00 \\
\hline & c. Jersey Klub Liga Lainnya & 39 & 26.00 \\
\hline \multirow[t]{3}{*}{5} & \multicolumn{3}{|l|}{ Kualitas jersey: } \\
\hline & a. Original & 89 & 59.30 \\
\hline & b. Non-Original & 61 & 40.70 \\
\hline \multirow[t]{3}{*}{6} & \multicolumn{3}{|l|}{ Memiliki akun Kaskus: } \\
\hline & a. Ya & 112 & 74.70 \\
\hline & b. Tidak & 38 & 25.30 \\
\hline
\end{tabular}

Pada Tabel 1 menunjukkan karakteristik demografis dari responden yang merupakan mahasiswa Universitas Trisakti yang pernah berbelanja jersey dan melakukan transaksi secara online di online shop yang tersedia dalam social media Kaskus dimana responden yang berusia antara 17 tahun hingga 20 tahun sebanyak 63 responden atau ditunjukkan berdasarkan persentase diperoleh sebesar 42 persen (42.00\%). Responden yang berusia antara 21 tahun hingga 29 tahun sebanyak 78 responden atau ditunjukkan berdasarkan persentase diperoleh sebesar 52.00 persen $(52.00 \%)$. Berikutnya responden yang memiliki usia di atas 30 tahun sebanyak 9 responden atau ditunjukkan berdasarkan persentase diperoleh sebesar 6.00 persen $(6.00 \%)$.

Karakteristik demografis dari responden yang merupakan mahasiswa Universitas Trisakti yang pernah berbelanja jersey dan melakukan transaksi secara online di online shop yang tersedia dalam social media Kaskus dimana responden yang berpendidikan terakhir SMA sebanyak 87 responden atau ditunjukkan berdasarkan persentase diperoleh sebesar 58 persen (58.00\%). Responden yang berpendidikan terakhir Diploma sebanyak 22 responden atau ditunjukkan berdasarkan persentase diperoleh sebesar 8.00 persen (8.00\%). Kemudian responden yang berpendidikan terakhir Sarjana Strata 1 
sebanyak 41 responden atau ditunjukkan berdasarkan persentase diperoleh sebesar 34.00 persen (34.00\%).

Karakteristik demografis dari responden yang merupakan mahasiswa Universitas Trisakti yang pernah berbelanja jersey dan melakukan transaksi secara online di online shop yang tersedia dalam social media Kaskus dimana responden yang berpenghasilan per bulan di bawah Rp1.000.000,- sebanyak 91 responden atau ditunjukkan berdasarkan persentase diperoleh sebesar 60.70 persen $(60.70 \%)$. Lalu responden yang berpenghasilan per bulan antara Rp1.000.000,hingga Rp5.000.000,- sebanyak 53 responden atau ditunjukkan berdasarkan persentase diperoleh sebesar 22 persen (22.00\%). Dan responden yang berpenghasilan per bulan di atas Rp5.000.000,sebanyak 6 responden atau ditunjukkan berdasarkan persentase diperoleh sebesar 4.00 persen (4.00\%).

Karakteristik demografis dari responden yang merupakan mahasiswa Universitas Trisakti yang pernah berbelanja dan melakukan transaksi secara online di online shop yang tersedia dalam social media Kaskus dan pernah membeli jersey klub liga Inggris sebanyak 78 responden atau ditunjukkan berdasarkan persentase diperoleh sebesar 52.00 persen $(52.00 \%)$. Responden yang membeli jersey klub liga Italia sebanyak 33 responden atau ditunjukkan berdasarkan persentase diperoleh sebesar 22 persen (22.00\%). Dan responden yang membeli jersey klub liga lainnya sebanyak 39 responden atau ditunjukkan berdasarkan persentase diperoleh sebesar 26 persen (26.00\%).

Karakteristik demografis dari responden yang merupakan mahasiswa Universitas Trisakti yang pernah berbelanja dan melakukan transaksi secara online di online shop yang tersedia dalam social media Kaskus dimana responden yang membeli jersey dengan kualitas original sebanyak 89 responden atau ditunjukkan berdasarkan persentase diperoleh sebesar 59.30 persen $(59.30 \%)$. Dan responden yang membeli jersey dengan kualitas non-original sebanyak 61 responden atau ditunjukkan berdasarkan persentase diperoleh sebesar 40.70 persen (40.70\%).
Dan terakhir karakteristik demografis dari responden yang merupakan mahasiswa Universitas Trisakti yang pernah berbelanja dan melakukan transaksi secara online di online shop yang tersedia dalam social media Kaskus dimana responden yang memiliki akun social media Kaskus sebanyak 112 responden atau ditunjukkan berdasarkan persentase diperoleh sebesar 74.70 persen (74.70\%). Dan konsumen yang tidak memiliki akun social media kaskus sebanyak 38 responden atau ditunjukkan berdasarkan persentase diperoleh sebesar 25.30 persen (25.30\%).

\section{Uji Validitas}

Uji validitas digunakan untuk mengetahui apakah semua item pertanyaan penelitian yang digunakan untuk mengukur variabel penelitian adalah valid. Pengujian validitas dilakukan dengan mencari korelasi dari setiap indikator terhadap skor totalnya dengan menggunakan rumus pearson correlation. Keputusan yang diambil dengan cara membandingkan nilai $p$-value dari setiap indikator dari variabel. Dasar pengambilan keputusan uji validitas adalah sebagai berikut : Jika $p$-value $<(0,05)$ maka item pernyataan valid. Jika $p$-value $>(0,05)$ maka item pernyataan tidak valid.

\begin{tabular}{|c|c|c|c|c|}
\hline \multicolumn{5}{|c|}{ Tabel 2. Hasil Uji Validitas } \\
\hline No & Variabel & Koefisien korelasi & $\mathrm{p}$-value & Keputusan \\
\hline \multirow[t]{6}{*}{1} & \multicolumn{4}{|c|}{ Behavioral Attitude } \\
\hline & Batt1 & 0.904 & 0.000 & Valid \\
\hline & Batt2 & 0.906 & 0.000 & Valid \\
\hline & Batt3 & 0.901 & 0.000 & Valid \\
\hline & Batt4 & 0.903 & 0.000 & Valid \\
\hline & Batt5 & 0.898 & 0.000 & Valid \\
\hline \multirow[t]{4}{*}{2} & \multicolumn{4}{|c|}{ Cognitive Perception } \\
\hline & $\operatorname{Cog} 1$ & 0.893 & 0.000 & Valid \\
\hline & $\operatorname{Cog} 2$ & 0.905 & 0.000 & Valid \\
\hline & $\operatorname{Cog} 3$ & 0.938 & 0.000 & Valid \\
\hline \multirow[t]{5}{*}{3} & \multicolumn{4}{|c|}{ Perceived Security } \\
\hline & Sec1 & 0.863 & 0.000 & Valid \\
\hline & Sec2 & 0.849 & 0.000 & Valid \\
\hline & $\operatorname{Sec} 3$ & 0.798 & 0.000 & Valid \\
\hline & $\operatorname{Sec} 4$ & 0.824 & 0.000 & Valid \\
\hline \multirow[t]{4}{*}{4} & \multicolumn{4}{|c|}{ Perceived Privacy } \\
\hline & Priv1 & 0.920 & 0.000 & Valid \\
\hline & Priv2 & 0.899 & 0.000 & Valid \\
\hline & Priv3 & 0.946 & 0.000 & Valid \\
\hline
\end{tabular}




\begin{tabular}{|c|c|c|c|c|}
\hline No & Variabel & Koefisien korelasi & $\mathrm{p}$-value & Keputusan \\
\hline \multirow[t]{7}{*}{5} & \multicolumn{4}{|l|}{ Fulfillment } \\
\hline & Ful1 & 0.745 & 0.000 & Valid \\
\hline & Ful2 & 0.924 & 0.000 & Valid \\
\hline & Ful3 & 0.908 & 0.000 & Valid \\
\hline & Ful4 & 0.905 & 0.000 & Valid \\
\hline & Ful5 & 0.897 & 0.000 & Valid \\
\hline & Ful6 & 0.918 & 0.000 & Valid \\
\hline \multirow[t]{6}{*}{6} & \multicolumn{4}{|c|}{ Perceived Trustworthiness } \\
\hline & Trust1 & 0.924 & 0.000 & Valid \\
\hline & Trust2 & 0.923 & 0.000 & Valid \\
\hline & Trust3 & 0.935 & 0.000 & Valid \\
\hline & Trust4 & 0.923 & 0.000 & Valid \\
\hline & Trust5 & 0.932 & 0.000 & Valid \\
\hline \multirow[t]{5}{*}{7} & \multicolumn{4}{|c|}{ Purchase Behavior } \\
\hline & Purc1 & 0.903 & 0.000 & Valid \\
\hline & Purc2 & 0.927 & 0.000 & Valid \\
\hline & Purc3 & 0.921 & 0.000 & Valid \\
\hline & Purc4 & 0.921 & 0.000 & Valid \\
\hline
\end{tabular}

Dari tabel di atas terlihat bahwa semua nilai p-value $>0.5$ sehingga dapat disimpulkan bahwa butir-butir dari pertanyaan tersebut dinyatakan valid, sehingga penelitian ini bisa dilanjutkan ke proses selanjutnya.

\section{Uji Reliabilitas}

Suatu uji reliabilitas pada alat ukur perlu dilakukan untuk memastikan instrumen dari alat ukur yang digunakan untuk penelitian ini adalah konsisten dan akurat. Reliabilitas berkaitan dengan konsistensi, akurasi, dan prediktabilitas suatu alat ukur. Menurut Sekaran (2006), dasar pengambilan keputusan uji reliabilitas ini adalah sebagai berikut:

a. Jika koefisien Cronbach's Alpha $\geq 0,6 \rightarrow$ maka Cronbach's Alpha acceptable (construct reliable).

b. Jika Cronbach's Alpha $<0,6 \rightarrow$ maka Cronbach's Alpha poor acceptable (construct unreliable).

\begin{tabular}{|c|l|c|c|c|}
\hline \multicolumn{5}{|c|}{ Tabel 3. Hasil Uji Reliabilitas } \\
\hline No & \multicolumn{1}{|c|}{ Variabel } & N of Items & Cronbach's Alpha & Keputusan \\
\hline 1 & Behavioral Attitude & 5 & 0.943 & Reliabel \\
\hline 2 & Cognitive Perception & 3 & 0.899 & Reliabel \\
\hline 3 & Perceived Security & 4 & 0.854 & Reliabel \\
\hline 4 & Perceived Privacy & 3 & 0.912 & Reliabel \\
\hline 5 & Fulfillment & 6 & 0.943 & Reliabel \\
\hline 6 & Perceived & 5 & 0.959 & Reliabel \\
\hline 7 & Purchase Behavior & 4 & 0.937 & Reliabel \\
\hline
\end{tabular}

Dari tabel di atas terlihat semua variabel dengan Cronbach Alpha yang lebih besar dari 0.60, sehingga variabel-variabel tersebut dinyatakan reliabel dan bisa dilanjutkan untuk penelitian selanjutnya.

\section{Metode Analisis Data}

Penelitian ini diujikan melalui metode analisis SEM dengan bantuan program software AMOS untuk menguji pengaruh behavioral attitude, cognitive perception, perceived security, perceived privacy, dan fulfillment melalui perceived trustworthiness terhadap purchase behavior. Metode analisis data yang digunakan dengan melihat tujuan penelitian adalah sebagai berikut:

1. Untuk mengetahui behavioral attitude berpengaruh positif terhadap perceived trustworthiness.

2. Untuk mengetahui cognitive perception berpengaruh positif terhadap perceived trustworthiness.

3. Untuk mengetahui perceived security berpengaruh positif terhadap perceived trustworthiness.

4. Untuk mengetahui perceived privacy berpengaruh positif terhadap perceived trustworthiness.

5. Untuk mengetahui fulfillment berpengaruh positif terhadap perceived trustworthiness.

6. Untuk mengetahui perceived trustworthiness berpengaruh positif terhadap purchase behavior.

\section{HASIL dan PEMBAHASAN \\ Hasil}

Hasil pengujian hipotesis penelitian bahwa Behavioral Attitude, Cognitive Perception, Perceived Security, Perceived Privacy, Fulfilment berpengaruh positif terhadap Perceived Trustworthiness dan Perceived Trustworthiness berpengaruh positif terhadap Purchase Behavior.

Adapun pembahasan dari masing-masing hipotesis penelitian sebagai berikut:

1. Behavioral Attitude berpengaruh positif terhadap Perceived Trustworthiness. Sikap dan perilaku konsumen (behavioral attitude) terhadap kepercayan pengguna (perceived 
trustworthiness) tentang suatu toko online mungkin didasari oleh kepercayaan dan persepsi resiko. Suatu sikap yang baik akan membentuk niat untuk bertransaksi secara online, kemudian diikuti oleh niat perilaku nyata dalam membeli dari toko online. Kepercayaan dibentuk oleh konsumen yang didasarkan pada informasi yang tersedia tentang toko online. Kepercayaan pada suatu toko online dapat menghasilkan suatu sikap yang baik oleh konsumen dan mungkin juga meningkatkan sikap secara tidak langsung dengan menurunkan persepsi resiko.

2. Cognitive Perception berpengaruh positif terhadap Perceived Trustworthiness. Persepsi konsumen tentang suatu toko online akan membentuk niat untuk bertransaksi secara online, kemudian diikuti oleh niat perilaku nyata dalam membeli dari toko online. Kepercayaan dibentuk oleh konsumen yang didasarkan pada informasi yang tersedia tentang toko online. Kepercayaan pada suatu toko online dapat menghasilkan suatu sikap yang baik oleh konsumen dan mungkin juga meningkatkan sikap secara tidak langsung dengan menurunkan persepsi resiko.

3. Perceived Security, persepsi adanya keamanan yang tinggi berpengaruh positif terhadap Perceived Trustworthiness, dan banyak alasan yang melatar belakangi yang membuat orang tidak tertarik untuk melakukan pembelian secara online salah satu diantaranya adalah faktor keamanan. Rasa aman mungkin menggambarkan subyektif sebagai kemungkinan konsumen percaya bahwa informasi pribadi mereka tidak akan dapat dilihat, dan berpindah tanpa persetujuan.

4. Perceived Privacy, privasi yang tinggi berpengaruh positif terhadap Perceived Trustworthiness, awalnya belanja melalui internet kurang diminati. Banyak alasan yang melatarbelakangi yang membuat orang tidak tertarik untuk melakukan pembelian secara online diantaranya adalah faktor privasi (perceived privacy). Rasa aman mungkin menggambarkan subyektif sebagai kemungkinan konsumen percaya bahwa informasi pribadi mereka tidak akan dapat dilihat, dan tidak akan berpindah tanpa persetujuan.

5. Fulfilment, kualitas layanan yang tinggi berpengaruh positif terhadap Perceived Trustworthiness, konsumen memutuskan untuk melakukan pembelian terhadap suatu produk karena produk tersebut dianggap dapat memenuhi kebutuhan atau memberikan manfaat (fulfillment) tertentu bagi konsumen, karakteristik produk tidak hanya meliputi aspek fisik (tangible features), tetapi juga aspek non fisik (intangible features) seperti citra dan jasa yang dapat dilihat. Faktor emosional, atau aspek afektif dalam teori pengambilan keputusan menyajikan bukti bahwa pemenuhan (fulfillment) dapat digunakan sebagai faktor positif untuk menyimpulkan kepercayaan (perceived trustworthiness) dan untuk membuat keputusan pembelian (purchase behavior).

6. Perceived Trustworthiness, kepercayaan pengguna (perceived trustworthiness) tentang suatu toko online mungkin didasari oleh kepercayaan dan persepsi resiko dari toko itu sendiri, dan dari kepercayaan dan persepsi resiko dari toko itu akan membentuk niat untuk bertransaksi secara online, kemudian diikuti oleh niat perilaku nyata dalam membeli dari toko online.

\section{Pembahasan}

\section{Statistik Deskriptif}

Statistik deskriptif adalah statistik yang menggambarkan fenomena atau karakteristik dari data yang diteliti dalam suatu situasi (Sekaran, 2006). Statistik deskriptif adalah suatu deskripsi mengenai pengumpulan, penyusunan, serta penyajian data berdasarkan nilai rata-rata (Mean) (Santoso, 2008). Hasil statistik dari variabelvariabel Behavioral Attitude, Cognitive Perception, Perceived Security, Perceived Privacy, Fulfillment, Perceived Trustworthiness, dan Purchase Behavior, dapat dilihat pada Tabel 4 di bawah ini : 


\begin{tabular}{|c|l|c|c|c|}
\hline \multicolumn{5}{c}{ Tabel 4. Statistik Deskriptif } \\
\begin{tabular}{|c|l|c|c|c|}
\hline No & \multicolumn{1}{|c}{ Variabel } & N & Mean & Std. Deviation \\
\hline 1 & Behavioral Attitude & 150 & 3.915 & 0.846 \\
\hline 2 & Cognitive Perception & 150 & 4.173 & 0.778 \\
\hline 3 & Perceived Security & 150 & 3.797 & 0.795 \\
\hline 4 & Perceived Privacy & 150 & 3.978 & 0.826 \\
\hline 5 & Fulfillment & 150 & 4.055 & 0.994 \\
\hline 6 & Perceived Trustworthiness & 150 & 3.841 & 1.057 \\
\hline 7 & Purchase Behavior & 150 & 3.843 & 0.918 \\
\hline
\end{tabular}
\end{tabular}

Nilai rata-rata Behavioral Attitude terlihat mayoritas pada statistik deskriptif yang terlihat dalam Tabel 4 diperoleh nilai rata-rata sebesar 3,915 maka menunjukkan sikap responden terhadap mahasiswa Universitas Trisakti yang pernah berbelanja dan melakukan transaksi secara online di online shop yang tersedia dalam social media Kaskus dengan standar deviasi sebesar 0,846 . Nilai rata-rata Cognitive Perception terlihat minoritas diperoleh nilai rata-rata sebesar 4.173 maka menunjukkan penilaian responden terhadap berbelanja dan melakukan transaksi secara online di online shop yang tersedia dalam social media Kaskus dengan standar deviasi sebesar 0,778.

Nilai rata-rata Perceived Security sebesar 3,797 maka menunjukkan responden berpendapat bahwa adanya keamanan yang lebih dari cukup untuk berbelanja dan melakukan transaksi secara online di online shop yang tersedia dalam social media Kaskus dengan standar deviasi sebesar 0,795. Nilai rata-rata Perceived Privacy sebesar 3,978 maka menunjukkan responden berpendapat bahwa adanya kerahasiaan yang lebih untuk berbelanja dan melakukan transaksi secara online di online shop yang tersedia dalam social media Kaskus dengan standar deviasi sebesar 0.826 . Nilai ratarata Fulfillment sebesar 4.055 maka menunjukkan responden berpendapat merasa adanya kualitas pelayanan melakukan transaksi secara online di online shop yang tersedia dalam social media Kaskus dengan standar deviasi sebesar 0,994.

Nilai rata-rata Perceived Trustworthiness sebesar 3,841 maka menunjukkan responden percaya untuk melakukan transaksi secara online di online shop yang tersedia dalam social media Kaskus dengan standar deviasi sebesar 1,057. Nilai rata-rata Purchase Behavior sebesar 3,843 maka menunjukkan responden berpendapat memiliki keinginan atau dorongan yang kuat untuk melakukan transaksi secara online di online shop yang tersedia dalam social media Kaskus dengan standar deviasi sebesar 0,918 .

\section{Hasil Uji Hipotesis}

\begin{tabular}{|c|c|c|c|}
\hline \multicolumn{4}{|c|}{ Tabel 5. Hasil Uji Hipotesis } \\
\hline Model & Estimate ( $\square$ ) & P-value & Keputusan \\
\hline $\begin{array}{l}\text { Cognitive_Perception } \rightarrow \\
\text { Perceived_Trustworthiness }\end{array}$ & 0.239 & 0.037 & $\mathrm{H}_{\mathrm{a} \mathrm{a}}$ diterima \\
\hline $\begin{array}{l}\text { Perceived_Security } \rightarrow \\
\text { Perceived_Trustworthiness }\end{array}$ & 0.508 & 0.000 & $\mathrm{H}_{1 \mathrm{a}}$ diterima \\
\hline $\begin{array}{l}\text { Behavioral_Attitude } \rightarrow \\
\text { Perceived_Trustworthiness }\end{array}$ & 0.246 & 0.008 & $\mathrm{H}_{1 \mathrm{a}}$ diterima \\
\hline $\begin{array}{l}\text { Perceived_Privacy } \rightarrow \\
\text { Perceived_Trustworthiness }\end{array}$ & 0.226 & 0.015 & $\mathrm{H}_{1 \mathrm{a}}$ diterima \\
\hline $\begin{array}{l}\text { Fulfillment } \rightarrow \text { Perceived_ } \\
\text { Trustworthiness }\end{array}$ & 0.312 & 0.002 & $\mathrm{H}_{1 \mathrm{a}}$ diterima \\
\hline $\begin{array}{l}\text { Perceived_Trustworthiness } \rightarrow \\
\text { Purchase_Behavior }\end{array}$ & 0.152 & 0.024 & $\mathrm{H}_{1 \mathrm{a}}$ diterima \\
\hline
\end{tabular}

Hipotesis 1:

Bunyi hipotesis null (H0) dan hipotesis alternatif $\left(\mathrm{H}_{\mathrm{a}}\right)$ adalah sebagai berikut:

$\mathrm{H}_{1}$ : Behavioral Attitude berpengaruh positif terhadap Perceived Trustworthiness.

Pada pengujian hipotesis 1 diketahui $p$-value $0,008<$ alpha 0,05 dengan nilai beta sebesar 0,246 maka $\mathrm{H}_{01}$ ditolak yang artinya Behavioral Attitude berpengaruh positif terhadap Perceived Trustworthiness. Sikap dan perilaku konsumen (behavioral attitude) terhadap kepercayaan pengguna (perceived trustworthiness) tentang suatu toko online mungkin didasari oleh kepercayaan dan persepsi resiko. Suatu sikap yang baik akan membentuk niat untuk bertransaksi secara online, kemudian diikuti oleh niat perilaku nyata dalam membeli dari toko online. Kepercayaan dibentuk oleh konsumen yang didasarkan pada informasi yang tersedia tentang toko online. Kepercayaan pada suatu toko online dapat menghasilkan suatu sikap yang baik oleh konsumen dan mungkin juga meningkatkan sikap secara tidak langsung dengan menurunkan persepsi resiko.

\section{Hipotesis 2:}

Bunyi hipotesis null $\left(\mathrm{H}_{0}\right)$ dan hipotesis alternatif $\left(\mathrm{H}_{\mathrm{a}}\right)$ adalah sebagai berikut:

$\mathrm{H}_{2}$ : Cognitive Perception berpengaruh positif terhadap Perceived Trustworthiness.

Pada pengujian hipotesis 2 diketahui $p$-value 
$0,037<$ alpha 0,05 dengan nilai beta sebesar 0,239 maka $\mathrm{H}_{02}$ ditolak yang artinya Cognitive Perception berpengaruh positif terhadap Perceived Trustworthiness. Persepsi konsumen tentang suatu toko online akan membentuk niat untuk bertransaksi secara online, kemudian diikuti oleh niat perilaku nyata dalam membeli dari toko online. Kepercayaan dibentuk oleh konsumen yang didasarkan pada informasi yang tersedia tentang toko online. Kepercayaan pada suatu toko online dapat menghasilkan suatu sikap yang baik oleh konsumen dan mungkin juga meningkatkan sikap secara tidak langsung dengan menurunkan persepsi resiko.

\section{Hipotesis 3:}

Bunyi hipotesis null $\left(\mathrm{H}_{0}\right)$ dan hipotesis alternatif $\left(\mathrm{H}_{\mathrm{a}}\right)$ adalah sebagai berikut:

$\mathrm{H}_{3}$ : Perceived Security berpengaruh positif terhadap Perceived Trustworthiness.

Pada pengujian hipotesis 3 diketahui $p$-value $0,000<$ alpha 0,05 dengan nilai beta sebesar 0,508 maka $\mathrm{H}_{03}$ ditolak yang artinya persepsi adanya keamanan yang tinggi berpengaruh positif terhadap Perceived Trustworthiness. Banyak alasan yang melatar belakangi yang membuat orang tidak tertarik untuk melakukan pembelian secara online salah satu diantaranya adalah faktor keamanan. Rasa aman mungkin menggambarkan subyektif sebagai kemungkinan konsumen percaya bahwa informasi pribadi mereka tidak akan dapat dilihat, dan berpindah tanpa persetujuan.

\section{Hipotesis 4:}

Bunyi hipotesis null $\left(\mathrm{H}_{0}\right)$ dan hipotesis alternatif $\left(\mathrm{H}_{\mathrm{a}}\right)$ adalah sebagai berikut:

$\mathrm{H}_{4}$ : Perceived Privacy berpengaruh positif terhadap Perceived Trustworthiness.

Pada pengujian hipotesis 4 diketahui $p$-value 0,015 < alpha 0,05 dengan nilai beta sebesar 0,226 maka $\mathrm{H}_{04}$ ditolak yang artinya persepsi adanya privasi yang tinggi berpengaruh positif terhadap Perceived Trustworthiness. Awalnya belanja melalui internet kurang diminati. Banyak alasan yang melatar belakangi yang membuat orang tidak tertarik untuk melakukan pembelian secara online diantaranya adalah faktor privasi (perceived privacy). Rasa aman mungkin menggambarkan subyektif sebagai kemungkinan konsumen percaya bahwa informasi pribadi mereka akan tidak dapat dilihat, dan tidak akan berpindah tanpa persetujuan.

\section{Hipotesis 5:}

Bunyi hipotesis null $\left(\mathrm{H}_{0}\right)$ dan hipotesis alternatif $\left(\mathrm{H}_{\mathrm{a}}\right)$ adalah sebagai berikut:

$\mathrm{H}_{5}$ : Fulfillment berpengaruh positif terhadap Perceived Trustworthiness.

Pada pengujian hipotesis 5 diketahui $p$-value $0,002<$ alpha 0,05 dengan nilai beta sebesar 0,312 maka $\mathrm{H}_{05}$ ditolak yang artinya kualitas layanan yang tinggi berpengaruh positif terhadap Perceived Trustworthiness. Konsumen memutuskan untuk melakukan pembelian terhadap suatu produk karena produk tersebut dianggap dapat memenuhi kebutuhan atau memberikan manfaat (fulfillment) tertentu bagi konsumen, karakteristik produk tidak hanya meliputi aspek fisik (tangible features), tetapi juga aspek non fisik (intangible features) seperti citra dan jasa yang dapat dilihat. Faktor emosional, atau aspek afektif dalam teori pengambilan keputusan menyajikan bukti bahwa pemenuhan (fulfillment) dapat digunakan sebagai faktor positif untuk menyimpulkan kepercayaan (perceived trustworthiness) dan untuk membuat keputusan pembelian (purchase behavior).

\section{Hipotesis 6:}

Bunyi hipotesis null $\left(\mathrm{H}_{0}\right)$ dan hipotesis alternatif $\left(\mathrm{H}_{\mathrm{a}}\right)$ adalah sebagai berikut:

$\mathrm{H}_{6}$ : Perceived Trustworthiness berpengaruh positif terhadap Purchase Behavior.

Pada pengujian hipotesis 6 diketahui $p$-value $0,024<$ alpha 0,05 dengan nilai beta sebesar 0,152 maka $\mathrm{H}_{06}$ ditolak yang artinya Perceived Trustworthiness berpengaruh positif terhadap Purchase Behavior. Kepercayan pengguna (perceived trustworthiness) tentang suatu toko online mungkin didasari oleh kepercayaan dan persepsi resiko dari toko itu sendiri, dan dari kepercayaan dan persepsi resiko dari toko itu akan membentuk niat untuk bertransaksi secara online, kemudian diikuti oleh niat perilaku nyata dalam membeli dari toko online. 


\section{SIMPULAN}

Berdasarkan uraian dan analisis yang telah dikemukakan pada bab sebelumnya, maka kesimpulan yang diperoleh dari penelitian ini adalah: Hasil pengujian hipotesis menurut kualifikasi menunjukkan bahwa perceived trustworthiness memiliki pengaruh yang kuat untuk melakukan transaksi secara online di online shop yang tersedia dalam social media Kaskus, dari variabelvariabel (Behavioral Attitude, Cognitive Perception, Perceived Security, Perceived Privacy, dan Fulfillment) yang digunakan dalam penelitian ini semuanya mempengaruhi persepsi kepercayaan (Perceived Trustworthiness) dan pengaruh nyatanya untuk melakukan transaksi secara online (Purchase Behavior).

\section{PENGHARGAAN}

Sumber pembiayaan menggunakan dana LPPM Universitas Pamulang dan dari dana pribadi penulis satu dan penulis dua. Ucapan terima kasih kami haturkan kepada pihak yang turut memberikan bantuan sehingga penelitian ini bisa selesai. Tentunya masih banyak kekurangan dalam penelitian ini, semoga kami dapat memperbaiki dan membuat penelitian lainnya, sehingga bermanfaat bagi perkembangan ilmu pengetahuan.

\section{DAFTAR PUSTAKA}

Ajzen I. (1991). The Theory of Planned Behavior, Organizational Behavior and Human Decision Processes, pp. 179-221.

Blackwell, R.D., Engel, J.F, and Miniard, P.W. (2003). Consumer Behavior, International Management, International Edition, Vol. 9.

Belanger F, Hiller J, Smith W. (2002). "Trustworthiness in Electronic Commerce, The Role of Privacy, Security, and Site Attributes", Journal of Strategic Information Systems. Vol. 11 No. 3, pp. 245-270.

Coursaris, C., Hassanein, K., and Head, M. (2003). "M-commerce in Canada: an interaction framework for wireless privacy", Canadian Journal of Administrative Sciences, Vol. 20, No. 1, pp. 54-73.
Dasgupta, S. (2002). Users of the world unite! The challenges and opportunities of social media. The Journal of Economic Perspectives, Vol. 16, No. 1, pp. 147-168.

Davis, FD. (1989). Perceived Usefulness, Perceived Ease of Use, and User Acceptance of Information Technology, MIS Quarterly, Management Information Systems, Vol. 13, pp. 319-339.

Durianto, Darmadi, Sugiarto, \& Budiman, Lie J. (2003). Brand Equity Ten, Jakarta: PT Gramedia Pustaka Utama.

Ebert, Ronald, J., and Griffin, Ricky, W. (1995). Business (8th Edition), pp. 287-290.

Evans, Mary F., Scott Gilpatric, Michael McKee and Christian A. Vossler. (2007). Managerial Incentives for Compliance with Environmental Information Disclosure Programs. In Environmental Economics, Experimental Methods.

International Journal of Management, Vol. 22, No. 4, pp. 542-555.

Ifinedo, P., Nahar N. (2009). “Interaction Between Contingency, Organizational IT Factors, and ERP Success", Industrial management and Data Systems, Vol. 109 No. 1, pp. 118-137.

Kahle LR., Seligman C., Olson JM., and Zanna MP. (1996). "The Psychology of Values", The Ontario Symposium, Vol. 8, Lawrence Erlbaum, Washington, DC.

Kotler, Philip \& Amstrong, Gary. (2008). PrinsipPrinsip Pemasaran, edisi 12, Jakarta: Erlangga.

Kozinets, R.V., de Valck, K., Wojnicki, A.C. and Wilner, S.J.S. (2010), "Networked narratives: understanding word-of-mouth marketing in online communities", Journal of Marketing, Vol. 74 No. 3, pp. 71-89

Lacovou CL, Benbasat I, Dexter AS. (1995). "Electronic Data Interchange and Small Organizations, Adoption and Impact of Technology", MIS Quarterly. Vol. 19 No. 4, pp. 465-485.

Lassar, W., Mittal, B. and Sharma, A. (1995). "Measuring customer-based brand equity", Journal of Consumer Marketing, Vol. 12 No. 4, pp. 11-19.

Laudon, K.C., and Laudon J.P. (1998). "Prentice 
Hall", Management Information Systems.

Loudon, D.L and Della, Bitta, AJ. (1993). Consumer Behaviour: Concepts and Applications (4th Edition). McGraw Hill: Auckland.

Luhmann N. (1979). "Trust and Power", Chichester, Wiley, UK.

Magi, A.W. (2003). "Share of wallet in retailing: the effects of customer satisfaction, loyalty cards and shopper characteristics", Journal of Retailing, Vol. 79 No. 2, pp. 97-106.

Mangold, W.G. and Faulds, D.J. (2009), "Social media: the new hybrid element of the promotion mix", Business Horizons, Vol. 52 No. 4, pp. 357-65.

McFarland, D.J, and Hamilton, D. (2006), "Computers in Human Behavior", Vol. 22, pp. 427-447.

Purkayastha. (2009). Journal of Heterocyclic Chemistry, Vol. 27 No. 3, pp. 743-751.

Pijpers, G.-G. M., \& van Montfort, K. (2005). An investigation of factors that influence senior executives to accept innovations in information technology.

Pitta, D.A. and Katsanis, L.P. (1995). "Understanding brand equity for successful brand extension", Journal of Consumer Marketing, Vol. 12 No. 4, pp. 51-64.

Punj, Girish N., Clayton L. Hillyer. (2004). "A Cognitive Model of Customer-Based Brand Equity for Frequently Purchased Products: Conceptual Framework and Empirical Results". Journal of Consumer Psychology 12 (1\&2), $124-31$

Sekaran, U. (2006), Research Methods for Business (4th ed), John Wiley \& Sons, New York.

Schiffman, Leon G. and Kanuk, Leslie Lazar. (2007). Consumer Behaviour. 9th Edition. New Jersey: Pearson Prentice

Schiffman, Leon G. and Kanuk, Leslie Lazar. (2000). Consumer Behaviour. Prentice Hall International.

Shareef MA., Kumar U., and Kumar V. (2008). "Role of Different Electronic Commerce (EC) Quality Factors on Purchase Decision", A Developing Country Perspective. Journal of Electronic Commerce Research. Vol. 9 No. 2, pp. 92-113.
Shareef MA., Kumar V., Kumar U., and Misra SC. (2008). "The Role of E Sellers' Overall Reputation on Trust Information, Purchase Intention, and Purchase Satisfaction", A Developing Country Perspective. International Journal of Electronic Marketing and Retailing. Vol. 2 No. 2, pp. 105-134

Shareef MA., Kumar U., Kumar V., and Dwivedi YK. (2009). "Identifying Critical Factors for Adoption of E-Government", Electronic Government, An International Journal, Vol. 6 No. 1, pp. 70-96.

Shareef MA., Kumar U., Kumar V., and Dwivedi YK. (2011). "E-government Adoption Model (GAM), Differing Service Maturity Levels", Government Information Quarterly, Vol. 28 No. 1, pp. 17-35.

Sikri, S. (2005). "Understanding the Adoption Behavior and Usage of Personal Digital Assistants Among Community" Journal of the American Association Vol. 45(2) pp. 244.

Simamora, Bilson. (2002). "Panduan Riset Perilaku Konsumen". Gramedia Pustaka Utama.

Taylor S., and Todd PA. (1995). "Understanding Information Technology Usage: A Test of Competing Models", Information System Research, Vol. 6, No. 3, pp. 144-176.

Thatcher, J., Bohman, P., Burks, M., Henry, S. L., Regan, B., Swierenga, S., Urban, M. D., and Waddell, C. D. (2002). Constructing Accessible Web Sites. Birmingham, UK.

Trusov, M., Bucklin, R.E. and Pauwels, K. (2009). "Effects of Word-of-Mouth Versus Traditional Marketing, Findings From An Internet Social Networking Site", Journal of Marketing, Vol. 73 No. 9, pp. 90-102.

Wahana Komputer. (2002). Apa dan Bagaimana E-Commerce, Semarang.

Wenats, Wuryanta. (2012). "Newmedia Theory" Scribd. 